\title{
Non-Governmental Actors and the Evolution of International Environmental Law (An Overview of the NGOs in Iran)
}

\author{
Maryamalsadat Moosavi \\ Senior Student of PhD in Environmental Law, Department of Environmental Law, Faculty of Environment \& Energy \\ Sience \& Research Branch, Islamic Azad University, Tehran, Iran
}

Jaafar Koosha

Corresponding author. Assocciate profeesor of Shahid Beheshti University, Tehran, Iran Email: Jkoosha@yahoo.com

\section{Sayyed Abbas Pourhashemi}

Assistante Professor, Sience \& Research Branch, Islamic Azad University, Tehran, Iran

Davood Hermidas Bavand

Full professor of University of Tehran in International law

\section{Doi:10.5901/mjss.2015.v6n6s6p46}

\section{Abstarct}

\begin{abstract}
Although International Environmental law is considered as one of the most practicable tools to protect and preserve the environment, this practicability depends on participation of all types of national and international groups and actors. In fact, protecting the environment is only feasible when all groups are involved. This is resulted from its complicated and also extensive nature. Thus, not only at an international level without participation of all groups, governmental and nongovernmental actors, and even civil societies does environmental law remain an intellectual concept, but also at national level cooperation of legal custodian of environment with all part of the society is absolutely necessary in order to protect and preserve the environment. According to international investigations and its conformity with national conditions, existence of NGOs and Civil Societies is an indispensable preliminary fact. However, it will not be an exaggeration, if we claim NGOs in Iran are obsolete compared to other countries. This is mainly resulted from situation of organization in Iran's legal system. According to the leading role of NGOs in environmental law development, in this study, we focus on legal vacuum regarding their partnership and possible solutions to remove impediments.
\end{abstract}

Keywords: International Environmental Law, International Actors, Hard Law, Soft Law, Non-governmental Organization

\section{Introduction}

In the late nineteenth century, non-state actors in the form of NGOs took leading role in humanitarian aid and development. On the one hand, they would show more creativity and flexibility in determining strategies and plans to enter the country, and on the other hand they are not responsible to provide compensation covering the loss of government property, on the grounds that they are mainly funded by private-sector voluntary aids. Thus, NGOs tend more to take risks, so that in the world society these Non-Governmental Organizations establish criteria for international behavior controlling actions of each individual government. However, according to classic system of international law roles and responsibilities were distributed among major actors which are states. Indeed, inter-governmental organization and non-state actors just played an observing role in implementation of rules and regulations, nevertheless; these roles have changed significantly today and this group of actors increasingly plays effective roles in different branches of international law, such as human law and environmental law, consequently; they take an effective role in writing the draft of international instrument and controlling over them. Hence, the importance of their participation in conventions and other official procedures, particularly in implementation of regulation and principals of international environmental law, cannot be denied. A study on various forms and contents of participation in international environmental law can 
demonstrate ways new actors enter and their roles in amendment and evolution of traditional international law concepts. Fundamentally, diversity of NGOs involvement in different field, such as human law, humanitarian law, development, environment and etc., create distinct approaches to these organizations which can vary from one country to another according to their activity type. That is, activity type of an organization is a key factor in states views and roles assigned to them.

\section{Part 1) International Non-state Actors:}

\subsection{Non-governmental organization formation}

Although so many voluntary associations existed throughout the history, present forms of non-governmental organizations at international level have developed over the last 2 centuries. One of the first kinds of these organizations is World Red Cross founded in 1863.

With the establishment of United Nation in 1945, the term of "non-governmental organization" emerged at the article 71 of chapter 10 of United Nations Charter.

The definition of International Non-Governmental Organization was first presented in 10/288 resolution on Feb 27th 1950 which is defined as: "any international organization not created by international treaties and conventions". [l.Beigzadeh 1379]

Indeed, the most comprehensive definition of non-governmental actors is the one assigning all following characteristics to it:

1- They are financially independent of states and are not under the effective control of central government. These organizations usually arise from civil societies, market economy, or politic trends.

2- They act and collaborate in networks extends beyond states; hence, they involve in trans-national relations to create strong linkage among political systems, economies, and societies.

3- They act consciously in a way whose first purpose is to influence international institutions or national political outcomes.

Globalization process in 21st century considerably increased the importance of NGOs. Finding a solution for many national problems was impossible. International treaties and organization, such as WTO, concentrated on large financial institutions interests. In order to stabilize this situation, NGOs founded with a focus on humanitarian issues, development, and sustainable development. A prominent example is "World Social Forum" an annual meeting held in January at the same time with It's greatest rival "World Economic Forum" held in Davos, Switzerland. 5th World Social Forum was held at Porto Alegre, Brazil and representatives from more than 1000 NGOs had participated. [Gupta, Joyeeta, 2005]

\subsection{International Non State Actors Examples:}

International:

- Earth System Governance Project (ESGP)

- Global Environment Facility (GEF)

- Intergovernmental Panel on Climate Change (IPCC)

- Word Conservation Union (IUCN)

- Greenpeace

- World Nature Organization (WNO)

- Friends of the Earth

- World Wide Fund for Nature (WWF)

- Green Cross International

- Interamerican Association for Environmental Defense

- International Network for Sustainable Energy (INFORSE)

National:

- European Environment Agency (EEA)

- Partnerships in Environmental Management for the Seas of East Asia (PEMSEA)

- European Environmental Bureau (EEB) 


\subsection{Non-State Actors and International Environmental Law Formation}

\subsubsection{Sources of International Environmental Law:}

Article 38(1) (c) of the statue of the international court of justice which was drafted in 1920 for its predecessor, permanent international court of justice, is recognized as a definitive statement of the sources of classic international law. According to this article primary sources are as follows:

a. international conventions, whether general or particular

b. international custom, as evidence of a general practice accepted as law

c. the general principles of law recognized by civilized nations and subsidiary means for the determination of rules are:

a. international judicial decisions and orders

b. the teachings of the most highly qualified publicists of the various nations( Doctorine)

However, these registrations reflect neither common international manner nor actions performed providing assistance to the development of new rules of international environmental law. For illustration, this article rejects all texts have been concluded by international organizations except for conventions, whereas these non-binding texts play an important role in international law development specially in the making and development of environmental law. Indeed, international approaches demonstrate these non-binding documents, which are not conventions, play an effective role in development of international environmental law. In general, sources of environmental law classifies into two categories: hard law and soft law.

\subsubsection{Non-State Actors Role on Soft Law in international Environmental Law system:}

This part includes declaration of International Conferences and International Organizasions.

\subsubsection{Non-State Actors and International Conference Declaration:}

Non-state actors which are founded so as to satisfy their supporters' desires have a long and turbulent history. In recent years their number is increasing, as their collaboration and partnership capacity is raised. As a case in point, about 275000 active NGOs exist in England. [E. Burleson 2010].

Inasmuch as information age simplified international communications, environmental groups are created owing to governments failures to combat environmental degradation. Over the last two decades, rapid advance occurred in scientific theories of environmental NGOs, besides; their persuading and influencing skills allow an effective participation in environmental conventions primary negotiations. Indeed, Environmental negotiations are generally conducted so that NGOs can get involved in a practical way. The role and impact of NGOs in this kind of negotiations is considerably more important than in commercial and disarmament negotiations. This is resulted from particular nature of environmental problems specially due to uncertainty in environmental related subjects and dangers threatening it. Consequently, NGOs would have a positive influence on board of representatives on account of giving more reliable and precise information.

Some of these environmental NGOs such as IUCN, Friends of the Earth, Greenpeace International, and WWF are so prominent, because of their global influence, that Brundtland Commission suggests that states should consult with NGOs to achieve their strategies, information, and resources. Moreover, they should allow active participation of NGOs in various aspects of environmental issues. [M. Betsill 2008 ,].

For illustration, IUCN proposes draft world charter for nature passed on general assembly of the United Nation on October 29, 1982. Besides, IUCN is engaged in drafting international covenant on environment and development since 1980. [ Sandrine Malejean, Dubois, 2011].

\subsubsection{Non-state Actors and International Organizations Declarations:}

IUCN and WWF played a more important role in shaping international environmental principles than other active nonstate actors at international level. Hence, we briefly review their performances:

\subsubsection{International Union for Conservation of Nature (IUCN):}

International union for conservation of nature and natural resources was established by France government in 19848. 
This union, indeed, is a non-governmental organization consisting of states, legal persons, and protection groups. In 1990, IUCN was advocated by about 62 governments, 108 legal persons such as universities, and more than 400 NGOs. To sum it up, it is attended by official and non-official representatives from almost 117 countries. [P. Birnie \& A. Boyle, 2002]

The IUCN was founded with the purpose of motivating and assisting international societies to conserve nature and ensuring a rational and ecologically sustainable use of nature. That is, its main mission is assessing renewable resources situations as well as improving the management of renewable resources by encouraging members to make environmental conservation regulations, training about preservation, and providing members with the required information. Therefore, they give advice to sates and organization on subjects related to conservation, gathering information and analyzing them, complexity of environmental protection criteria, concluded conventions about technical conservation regulations, and motivating states to implement new strategies.

IUCN's tasks are as follows:

a- to conserve the environment, specially biodiversity, as a fundamental resource for future generations

b- to ensure that any use of natural resources is sensible, equitable, and ecologically sustainable

c- to lead humane society to development while considering the dynamic of ecosystem's caring capacity

The organizational structure of IUCN is similar to Intra-governmental organizations. A general assembly holding a meeting every three years, a council whose member chosen by general assembly to implement programs and policies, and a Secretariat performing task during space between conferences are its primary parts.

One unusual aspect of IUCN is the importance it gives to its six commissions which are made up of 3000 volunteer professionals. Among these six commission world commission on environmental law is responsible for environmental issues. Their core business is giving a clear guideline to states. Furthermore, IUCN has published world Conservation Strategy regularly since 1980 . The strategy addresses general authorities and encourages them to be integrated in implementing developmental policies for conserving and protecting living resources. [ S. Haji vali mirza, 1389] World Conservation Strategy, in law related subjects, has designed some regulations in order to protect tropical forests, dry areas, high seas, atmosphere, and Antarctica. It has also created a regional strategy to give rise to the protection of common living resources particularly in the oceans and coastal areas of international rivers.

Several publications strengthen the World Conservation Strategy. The IUCN Red List assesses the risk of extinction to threatened species including mammalians, amphibians, reptiles, invertebrates, birds, and plants. IUCN, furthermore, every year publishes a report of endangered species, national parks, and protected areas. Information about ecological problems and IUCN's activities, particularly the utilization of World Conservation Strategy, is given in the monthly Bulletin. [Francoise Burhenne-Guilmin, 2004]

Last but not least, Environmental Law centre located in Bonn, Germany houses 2 extensive libraries on Legislations, Treaties and Case Law, and literature and Soft Law.

\subsubsection{World Wildlife Fund (WWF):}

The popularity of this international non-governmental organization arises from its symbol, Giant Panda. Their main mission is gathering information, management, and providing loans and grants with the purpose of protecting and preserving the natural environment of living and non-living things on Earth.[ Winter,G, 2006] The idea for establishment of this fund was first proposed by British businessman Victor Stolan in his letter written on December 6th, 1960 to Sir Julian Huxley, the first director of UNESCO. In his letter he recommended that an international campaign should be set up to raise funds and provide grants for environmental conservation with a focus on protecting endangered species. WWF was officially founded on September 1961. It, indeed, is considered as a private-sector whose central secretariat (called WWF International) is located in Gland, Switzerland since 1978; also, WWF has have a close cooperation with IUCN. Beside its organizational structure, such as administrative councils, executive committee, and a director, the fund has a unique structure which is an international council consisting of representatives from 23 industrialized countries, as well as India, Indonesia, and Pakistan. These representatives play a vital role in fundraisings. [Young, 0. R, 2009] WWF fulfills activities, particularly implementing and fundraising for common programmes, by working with a large number of international organizations like UNEP. However, its main partners are non-governmental organizations specially IUCN. Every year, these two organizations cooperate to build a general strategy and make decisions on their determined programme. Then, they classify tasks into two categories. IUCN performs scientific and specific tasks, while WWF is responsible for financial sections. [Kiss, Alexandre, 2004]

WWF has performed great functions in the field of international law by advocating the utilization of regulations and norms; for illustration, it played a critical role in implementation of CITES (1972), Bonn (Conservation of Migratory 
Species of Wild Animals, 1979), and Ramsar (1971) conventions. Moreover, the fund did a great deal towards forming and developing the World Conservation Strategy in 1980. [ Franscoise Burhenne-Guimin, 2004]

In some cases, World Wildlife Fund advocates movements against projects threatening environment. For example, in the event of hydroelectric dam on Danube River which would have destroyed one of the last great stretches of wet riverside in Europe, WWF tried to terminate the project due to environmental and economic concerns. In January 1985, the Austrian Supreme Court ruled in favour of WWF, consequently, Austrian government agreed to leave the project in September 1986. Furthermore, WWF proposed environmental friendly solutions to international dispute over Danube Dam between Slovakia and Hungary in 1990. [ICJ Cases, 1990]

\subsubsection{Non-State Actors and Hard Laws in International Environmental Law System}

\subsubsection{Non-State Actors and Treaties:}

Non-governmental organizations often play an important role in democratic societies on the grounds that they emphasize on different perspective and different analysis from experienced political parties. Salient characteristics of international environmental negotiations are these organizations which not only have a great impact on their countries but also govern other states and international relations. Thus, we will face their dual roles, in international negotiations. This arise from that NGOs try to influence both states at national level and negotiators from all sides which may result in hindering negotiation process when NGOs take advantage of one side.

\subsubsection{IUCN:}

Organizational structure, aims, history, and activities of Union was mentioned in previous sections; hence, to avoid protracting we briefly refer to its fundamental role in developing and building about 12 environmental treaties designed to protect and preserve the nature and natural resources. We can name African Convention in 1968, CITES in 1973, and Berne Convention in1979 as cases in point.

\subsection{Non-state Actors and Development of international Environmental Law}

One may question that which interactions would be more beneficial in the development of international environmental law?

The answer is to concentrate on the role of each international actor in order to face environmental issues can bring about desired result, owing to the fact that everyone would confess an international collaboration is required to deal with global problems. Inasmuch as governments have lost their unique role and non-state actors have gained a position in decision making, NGOs seek to engage in international diplomacy, as well as influencing states. Investigations on international environmental policies led us to pay attention on non-state actors' roles in different environmental issues and to explore states' positions in this field. These studies, also, create questions concerning national and international domain of political activities. Some theories of international relationships separate these domains, whereas this division seems irrational since solving environmental complications beyond states require a healthy and strong transnational cooperation. Indeed, relationships between organizations, international institutions, non-state entities, etc., particularly in exploiting international programme and policies for environmental conservation, are pretty tortuous. This is true not only about cause and effect relationships and what environmental troubles bring about in modern world but also about ways chosen and decisions made.

[Beyerlin, Ulrich, 2009] The role transnational and regional organizations, financial entities, and scientists play is crucial in encountering environmental troubles. The areas these actors focus are not restricted by the boundaries of one specific country, as it can be perceived from their designations.

Furthermore, role of public opinion representatives as powerful actors in the process of making law and regulations has been revealed in Rio Convention and Ozone Layer Protection treaty negotiations. As specialist they abet to complete International environmental legal regime, participate in negotiations and decisions at global level as an initial stimulus or a reliable source for scientific information, prepare draft for important agreements, and even appear at meetings as official representatives of states. [UNEP, 2009]

NGOs ability in facilitating networking, in particular regional networks which are directly connected with environmental issues, makes them a key factor in enhancing sustainable development. NGOs adaptability and flexibility expedite fulfilling functions with no official affiliations and by public advocacy and protection. NGOs members as pioneers 
in promoting public awareness about environmental issues, such as maintaining environmental standards, take actions as pressure group on the establishment of environmental culture in large national projects and engage in monitoring while implementation is in progress. These organizations take part in employing governments' programme by developing networks and strong links with community groups without the need for unnecessary bureaucracy. Moreover, they can take steps to promote quality of life, relief suffering, conserve environment, give rise to national welfare, and achieve sustainable development independently from governmental organizations. [Golshan chehre, mohammad reza,1380]

\subsubsection{Non-state actors activities in the field of international environmental law}

In history of international law, states were often the only entities addressed and other institutions lacked jurisdiction to take disciplinary action. However, a transition process occurred in 21th century during which the need for non-state actors was revealed. Most NGOs cooperate with states and international entities and seek to influence policy makers for promotion of environmental guidelines. Non-governmental organizations, as a whole consisting of different components, are representative of all their individual members; besides, they make efforts to enhance their common values and aims.

Having access to finances, drawing media attention, and gaining, communicating, and publishing experts knowledge are considered as some of their myriad capacities. Furthermore, their transnational legitimacy allows NGOs to force international institutions into transparent performance. They can bring up varied questions, front communities in order for a specific reason, and design templates; in fact, they are moral organization for amendment at their goal state. [ Joyeeta Gupta, 2003]

The power of NGOs is usually utilized to stabilize commercial interests and environmental protection. Nevertheless, industries can themselves partner in implementing international environmental law. For example, some chemical material companies exist that use chemical substitutes for ozone-depleting materials to abide by ozone layer protection regime. In this field, Insurance organizations have done several researches about climate change and have advocated activities related to removing greenhouse gases from atmosphere. As another case in point, we can consider representatives of tourism industry attending in the Antarctic Treaty Consultative Meeting. [Yamin Farhana 2001]

Agenda 21, voluntarily implemented action plan of the United Nations with regard to sustainable development, in order for strengthening the role of major groups suggest international finance and development agencies, and all

Intergovernmental organizations and forums that they should perform following actions in consultation with NGOs:

a- Review and report on ways of enhancing existing procedures and mechanisms by which non-governmental organizations contribute to policy design, decision-making, implementation and evaluation at the individual agency level, in inter-agency discussions and in United Nations conferences;

b- On the basis of sub paragraph (a) above, enhance existing or, where they do not exist, establish, mechanisms and procedures within each agency to draw on the expertise and views of non-governmental organizations in policy and programme design, implementation and evaluation;

c- Design open and effective means of achieving the participation of non-governmental organizations in the processes established to review and evaluate the implementation of Agenda 21 at all levels;

d- Provide access for non-governmental organizations to accurate and timely data and information to promote the effectiveness of their programmes and activities and their roles in support of sustainable development. [ Rio Declaration, 1992]

\subsubsection{NGOs Actions in order for Development of Environmental Law}

Social researches reveal this fact that public trust towards NGOs (regarding their popularity) is more than governments; therefore their ability in affecting fundamental developments is a result of this fact and likewise that scientific and environmental institutes which have technical expertise regularly are in need of policy-making processes in the field of international environment.

\subsubsection{Achieving the official status among international institutions}

Most of NGOs have been able to reach a legislating status among international institutes as article 71 of UN charter provides:

Economic and social council can establish an "advisory status" for NGOs that have observed the criteria for UN establishment. Such status makes an NGO deserve the access to UN conferences and sessions and in some cases the right to verbal intervention and providing written proposals. [Beigzade, Ebrahim, 1379] 


\subsubsection{Attendance in Rio and Stockholm circuits:}

The NGOs had a significant attendance in RIO and Stockholm Conference, so that in Earth Summit (Rio 1992) the representatives of almost 1500 NGOs were present for attending formal and informal sessions. They were allowed to lobbying, provide instruments and lay sessions among them. Subsequently, NGOs attended in conferences for Tokyo protocol and other agreements alike and also undertook an overall supervision in international environmental treaties , indeed they had a significant role in revealing international necessities. (Shoarian sattari, Elnaz, 1384)

\subsubsection{Possessing Key Factors to create coordination:}

Council of Europe decision on March 1st, 2002 provides international NGOs (INGOs) with the opportunity to acquire participatory status, as well as its emphasis on NGOs major role as environmental actors. Moreover, it was revealed that NGOs have main factors required for creating coordination and are considered as a network for European Commission's viewpoints on commission outlook, on the grounds that commission cannot deal with governments and lower level groups. These organizations, also, have a better understanding of public environmental concerns; thus, they can reflect their point of view and transfer them to European Union Commission. [ European Environment Agency, 2010]

\subsubsection{Cooperation with World Bank in project assessment:}

World bank concluded operational directive 14.70 dated August 28, 1989, which sets out a framework for involving nongovernmental organizations (NGOs) in Bank-supported activities.

This directive permits bank to consult with NGOs regarding the assessment of developmental programme and their approval as a resource for information. Hence, NGOs would serve a consulting function, take actions as an information resource or even a project moderator. [ Betsill, M.M. and correll, 2008]

\subsubsection{Participating in sustainable development commission meetings:}

Agenda 21 encourage commission on sustainable development to be open to NGOs. Besides, resolution 47/191 of 22 December 1992, recommended that the Commission should validate the role of NGOs and allow them to attend in commission making law meetings. Non-Governmental Organizations ability in facilitating networking, in particular regional networks which are directly connected with environmental issues, makes them a key factor in enhancing sustainable development. Moreover, they can take steps to promote quality of life, relief suffering, conserve environment, give rise to national welfare, and achieve sustainable development independently from governmental organizations. [2008, Betsill, M. M. and Correll, E ]

\subsubsection{Mobilizing Public Opinion for environmental issues:}

NGOs members as pioneers in promoting public awareness about environmental issues, such as maintaining environmental standards, take actions as pressure group on the establishment of environmental culture in large national projects and engage in monitoring while implementation is in progress. Furthermore, these organizations make efforts out of institutes to mobilize public opinion, unveil environmental jeopardies, and create guidelines due to their formal role. NGOs adaptability and flexibility expedite fulfilling functions with no official affiliations and by public advocacy and protection. Globalization process promoted this role of NGOs and increased their capacity in mobilizing public opinion. Indeed, these organizations take part in employing governments' programme by developing networks and strong links with community groups without the need for unnecessary bureaucracy. [Golshan Chehreh, Mohammad Reza, 1380]

\subsubsection{Building the draft of environmental regulations and Laws:}

Non-Governmental organizations may create draft of regulations, or even enhance the approval of norms for their government, as well as for proposal to other states. These organizations, also, gather information and monitor adherence to international binding and non-binding regulations and standards. It is not out of place to mention that these regulations are not created by just one group of international actors; indeed, they are arise from complicated interactions between various state and non-state actors. so that all of them increasingly partner in creating, implementing, and utilizing national and international norms. 
Today, development of transnational norms and standards do not exist in many environmental aspects, as personal Standardization is considered incorrect. In fact, interaction method between states and non-state actors, particularly to accomplish adherence to soft law norms, may be imperative.[ Bombay, Peter, 2001]

\subsubsection{Development of international environmental standards:}

Following example can definitely specify the significant role of NGOs in thriving international norms and standards:

a- IUCN had a critical role in creating World Charter for Nature and compelling UN to conclude it.

b- International Law Association approved Helsinki Rules on uses of waters of international revers in 1966 which led to several conventions about international streams such as South Africa agreement with Namibia on the establishment of a permanent Water Commission. [Kiss, Alexandre, 2004]

\subsubsection{Participating in Mediterranean Commission on Sustainable Development (MCSD)}

Besides cases mentioned before, we can refer to Mediterranean Commission on Sustainable Development created in 1995. The commission is made up of 36 members: 21 members representing their states, as well as 15 representatives from environmental NGOs. That is, this commission permit non-state actors membership and even all its member( states and non-states) are at the same level, while this commission is just a consulting organization and no voting is done.[ Kubasek,K, 2011]

\section{Part 2: NGOs of Iran and Development of Environmental Law:}

\subsection{A number of NGOs of Islamic Republic of Iran and their Theme}

These NGOs has been funded in 1994- 2012 and active today.

Table 1 - Some of the NGOs's names which have been founded since 1991 till 2011and are active as follows:

\begin{tabular}{|c|c|c|c|c|}
\hline The field of activity & $\begin{array}{l}\text { Geographic area } \\
\text { of founation }\end{array}$ & Foundation forum & $\begin{array}{l}\text { The date of } \\
\text { foundation }\end{array}$ & The instititut's title \\
\hline $\begin{array}{l}\text { Instruction and cultualize on reduction of } \\
\text { disadvantages of new energies and } \\
\text { reduction of environmental contimants }\end{array}$ & national & Ministry of interrior & 2011 & The light \\
\hline $\begin{array}{l}\text { Instructions on culture developments, } \\
\text { environmental management }\end{array}$ & national & $\begin{array}{l}\text { Iran's Chamber of commerce } \\
\text { and industries and mines }\end{array}$ & 2008 & $\begin{array}{l}\text { The association of Iran's green } \\
\text { management }\end{array}$ \\
\hline IT and environment & national & Youth national organization & 2008 & The green rain organization \\
\hline $\begin{array}{l}\text { Environmental instructions and } \\
\text { researches }\end{array}$ & national & $\begin{array}{l}\text { The record companies' } \\
\text { organization }\end{array}$ & 2008 & Parto Invertebrates institutes \\
\hline $\begin{array}{l}\text { Instructions, nature's guide, } \\
\text { environmental researches }\end{array}$ & national & $\begin{array}{l}\text { Cultural heritage, tourism and } \\
\text { crafts organization }\end{array}$ & 2007 & Iran's nature institute \\
\hline Women and environment & national & \begin{tabular}{|l|} 
Environmental protection \\
organization
\end{tabular} & 2007 & South's women forum \\
\hline Facilitation, life skills & national & $\begin{array}{l}\text { The record companies`' } \\
\text { organization }\end{array}$ & 2006 & \begin{tabular}{|l|} 
Women's pioneer green \\
development cooperation
\end{tabular} \\
\hline $\begin{array}{l}\text { Environmental and Facilitation } \\
\text { instructions }\end{array}$ & national & $\begin{array}{l}\text { The record companies } \\
\text { organization } \\
\end{array}$ & 2006 & Pioneer facilitatorinstitute \\
\hline environmental & national & Ministry of interrior & 2006 & Healthy world institute \\
\hline $\begin{array}{l}\text { Youth, nature and environmental } \\
\text { instructions }\end{array}$ & national & Ministry of interrior & 2006 & Nature's assistants forum \\
\hline environmental & national & $\begin{array}{l}\text { The record companies } \\
\text { organization }\end{array}$ & 2005 & Land's plan \\
\hline Environmental, soil and mountains & tehran & Ministry of interrior & 2005 & The green mountain institute \\
\hline Environmental instruction and research & national & Ministry of interrior & 2003 & Earth's supporters group \\
\hline environmental & tehran & Ministry of interrior & 2003 & Ecological researchers forum \\
\hline $\begin{array}{l}\text { Women, youth, nature, sports and } \\
\text { environment, wildlife and biodiversity, } \\
\text { pollutions and environmental instructions }\end{array}$ & national & Ministry of interrior & 2003 & Borna naturalist's forum \\
\hline \begin{tabular}{|l|} 
Cultualization and environmental \\
instructions
\end{tabular} & national & $\begin{array}{l}\text { Environmental protection } \\
\text { organization }\end{array}$ & 2002 & Pars green gates \\
\hline Environmental, science-research & national & The record companies & 2002 & Earth green idea forum \\
\hline
\end{tabular}




\begin{tabular}{|c|c|c|c|c|}
\hline & & organization & & \\
\hline $\begin{array}{l}\text { Pollutions, Nature and environmental } \\
\text { instructions }\end{array}$ & national & Ministry of sceince & 2002 & Iran's valuation forum \\
\hline Nature and environmental instructions & national & $\begin{array}{l}\text { The record companies` } \\
\text { organization }\end{array}$ & 2001 & Cheetah protection forum \\
\hline Nature and environmental instructions & national & Ministry of interrior & 2001 & Iran's nature forum \\
\hline environmental & national & $\begin{array}{l}\text { The record companies } \\
\text { organization }\end{array}$ & 2001 & Iranian cheetah forum \\
\hline environmental & national & Ministry of interrior & 2000 & The green development institute \\
\hline environmental & national & $\begin{array}{l}\text { Environmental protection } \\
\text { organization }\end{array}$ & 2000 & $\begin{array}{l}\text { Environmental protection } \\
\text { retirement centre }\end{array}$ \\
\hline environmental & national & Ministry of interrior & 2000 & $\begin{array}{l}\text { Sustainable development and } \\
\text { earth's women institute }\end{array}$ \\
\hline Environmental researches & national & $\begin{array}{l}\text { The record companies } \\
\text { organization }\end{array}$ & 2000 & The green village development \\
\hline environmental & $\begin{array}{l}\text { National and } \\
\text { international }\end{array}$ & $\begin{array}{l}\text { Environmental protection } \\
\text { organization }\end{array}$ & 2000 & Earth's scout centre \\
\hline Nature and environmental instructions & national & $\begin{array}{l}\text { The record companies } \\
\text { organization }\end{array}$ & 1999 & Nomad's ecosystems institute \\
\hline Natural environment & national & $\begin{array}{l}\text { The record companies } \\
\text { organization }\end{array}$ & 1999 & $\begin{array}{l}\text { Ecosystems and biodiversities } \\
\text { institute }\end{array}$ \\
\hline environmental & national & $\begin{array}{l}\text { Environmental protection } \\
\text { organization }\end{array}$ & 1998 & The green civilization forum \\
\hline $\begin{array}{l}\text { Pollutions, nature and environmental } \\
\text { instructions }\end{array}$ & national & $\begin{array}{l}\text { Ministry of sciwnce and } \\
\text { research }\end{array}$ & 1995 & Environments technicians forum \\
\hline
\end{tabular}

\subsection{Current situation of non-governmental organizations in Iran:}

On the whole, according to table above, the variety in the function of these organizations in Iran, is such that makes it difficult to provide a single definition. However, these organizations have common issues such as having a private nature and being non-commercial.

According to Iran's law, commercial code and the regulation on registration of non-commercial institutes approved in 1958 are regarded as the first provisions that have defined NGOs. About environment, the non-official organization of peoples of Ashkzar Village is regarded as one of the first environmental NGOs in Iran which has been founded in 1970 in order to repel the invasion of dune sand. [Haji vali mirza, Sara, 1385]

In the recent couple decades, Islamic Republic of Iran has been testifying the significant qualitative and quantitative development of NGOs. Certainly one of the substantial and important factors regarding the increase in number of these organizations is in realization of association based culture in all affairs such as environmental issues as it has been noted in some international instruments like article 10 of Rio declaration 1992 on environment and development.

\subsection{Non-governmental organizations in Islamic Republic of Iran's statute}

\subsubsection{Islamic Republic of Iran's constitutional code:}

Constitutional codes in most countries have been affected by advanced principles in universal declaration of human rights. One of the prevised matters in the aforesaid declaration is "the right to freedom of assembly" and according to this right "every person is entitled to enjoy the freedom of foundation of peaceful communities, assemblies and associations" (article 20 of universal declaration of human rights 1948).

Islam Republic of Iran's legislature has codified article 26 of constitutional law inspired by the principle of freedom of communities in this declaration, as such "parties, societies, political corporation associations and Islamic associations and known religious minorities enjoy freedom, provided that they do not violate the principles of independence, freedom, national unity, Islamic standards and the basics of Islamic Republic. People cannot be prohibited from participating or force them to participate in one." Article 26 of Iran's constitutional code deals with two subjects regarding establishment of NGOs: first: principle of freedom of communities, second: principle of freely participation in these communities. Indeed, the legislator has been seeking to establish a framework for civil assemblies (NGOs) using terms like communities, associations and besides in the latter section of this principle people's right to participate or not participate in any of these assemblies has been noted explicitly. 


\subsubsection{Statutes provided by Islamic parliament:}

Regarding measures mentioned in statutes we can refer to program rules initially. These statutes include all dimensions of development in economic, political, social and cultural fields and in order to determine state's purposes and general programs are regulated. Studying these provisions indicates growing process of attention to environmental policies and strengthening the role of NGOs.

Protecting the environment in country's macro program has been started from the first program and gradually has been supported in the next programs. Some matters have been paid special attention to in these programs such as establishment of NGOs in order to strengthening ordinary people`s participation in taking necessary measures for efficient supervision over enforcement of environmental provisions. [first development program cod, 1989]

One of the manifest points of the second program is emphasizing the increase in the role of civil participation for protecting environment. Therefore, civil participation office was established in the formation of environment protection organization in order to have more interaction with civil societies and NGOs protecting environment. This resulted in establishing a large number of NGOs protecting environment all over the country. Hence, the number of these organizations which was less than five in the early 60s, increased to 166 organizations in the mid-years of second program. [Second development program cod, 1994]

Subsequently in the third program, article 104 in 2 paragraphs deals with environment and environmental NGOs. Article 104 paragraph 2 of the third program provides: "in order to strengthen and support NGOs protecting environment and natural resources, individuals and legal persons' financial aids to these organizations is rendered as acceptable fee." The milestone of the third development program regarding protecting environment is summarized in 2 points: firstly, it considers institutionalizing civil partnership in planning, making decisions and running plans in order to maintaining the environment balance and secondly, pays special attention to strengthening and supporting NGOs financially [third development program cod,1999].

In the fourth development plan provisions, the process of paying attention to the subject of environment and NGOs has been going on and it has been mentioned in various articles like article 64 (enhancing the public awareness and access to sustainable development in order to protect the environment) and article 98 (civil partnership in sustainable development and quantitative and qualitative development of civil institutions). But in article 140 obviously emphasizes NGOs participation and other sections of civil society in directing country's matters and allows the government to take these measures:

1- Assist to establish and develop and regulate necessary NGOs in order to protect environment and enhance environmental standards on the basis of target centralized and responsibility

2- Establish an effective organizational unit for strengthening and supporting non-governmental section in the fields of institutionalization, education, providing facilities, justifying and removing barriers [fourth development program, 1384].

By studying the articles concerning these four planning provisions, it is concluded that these articles include three important subjects as follows:

- Teach environmental issues and provide information

- Institutionalize civil partnership and establish civil institutions

- Regulate NGOs.

The first step in order to realize a part of targets determined in the fourth development program took by means of approval of the by law for establishment and activity of NGOs in 1384. But in 1390 by approving the fifth development program the government took a rollback regarding civil partnership and NGOs and regardless of the importance of NGOs has mentioned briefly in article 190, not in order to develop them but to help decrease state's fees. While in the previous four programs important steps had been taken in order to enhance them and increase the role of this group of actors in protecting environment and subsequently in developing enforcement of environmental law, in the fifth development program in the chapter 6 as regional development deals with environment subject and in article 190 has mentioned to NGOs:

"All executive systems and public non-governmental institutions are obliged in order to decrease governments' fees, apply policies on efficient consumptions of basic resources in order to enforce green management plan including consumption management of energy, water, basic materials and equipment (including paper), decrease in solid trash and recycle them (in buildings and vehicles) according to the by law prepared by protection of environment organization and in cooperation with concerned sections and approved by committee of ministers" [the fifth development program, 1390]. 


\subsubsection{Formation of NGOs according to the executive by law for establishment and activity of NGOs}

On the whole the quantitative development of NGOs in Iran was significant in the recent years and environmental NGOs development was so much and almost 500 organizations exist in this regard which are active in national, regional and local levels. [environment protecting organization's official website, 1393] the formation and establishment process of this organization include terms and conditions which has been specified in details in the executive by law for establishment and activity of NGOs. Subtilizing in this by law indicates that various organizations are important in the process of formation in an NGO. Perhaps multiplicity of institutes for the formation of an NGO lies in multiplicity of jurisdiction; as, according to the by law, organs like ministry of information, ministry of interior, department of justice and the police force and other technical sections play an important role in formation and establishment of an NGOs. In this regard ministry of interior plays the most important role and seeks assistance from other institutes in order to review general and technical jurisdictions of applicants for establishing NGOs. For instance, applicants of establishing an environmental NGO must provide their application for taking the license to supervisory institutions including town supervisory board (including governor, town Islamic council representative and NGOs representative in town) and province supervisory board (including governor-general, province Islamic council representative and NGOs representative) and state's supervisory board (including deputy of ministry of interior, provinces high council representative and NGOs representative). After this step, according to article 22 of this by law, the supervisory board is obliged to catch the authority's opinion in one week from the date of receiving the application and the authority is obliged to announce its opinion at most in one week, otherwise its opinion is regarded as adherent. According to the subject of interest for the applicant organization, the supervisory institutions ask for competent section's opinion which regarding the applicant environmental NGO, this task is submitted to environmental protection organization, as this organization is generally responsible for protecting the environment in the whole country. [Abdollahi, Mohsen, 1388].

In practice, according to this by law and other provisions environmental NGO will be having legal personality after taking the license and subsequently the organization is regarded as registered and according to the provisions, is able to have activities within the standards determined in its statute.

\subsection{Interaction between environmental NGOs and government in order to environmental law development}

The relationship between government and NGOs is considerable from various perspectives. This relationship according to the field under study is variable. Essentially, the NGO's presence and partnership in environmental law is obtained during two processes as following:

- Formation of international norms

- Supervise and implement them

According to Iran's membership and partnership in most international treaties from past years to the present, executing treaty's norms and commitment to them is government's priority. Therefore, in this regard all organ's cooperation and partnership is necessary. On the other hand, variety and complexity in environmental components and provisions has resulted in different roles that its efficient execution lays on a part of the society. Although it is explicit that government's role generally and environment lawful authorities specifically, is more important and effective that other organs, but NGOs in this section, have a special role that in one section appears as the supplement for government's activity and as government's rival in another section. Basically due to wide range of government's activities in various sections, this necessity is often seen from the government that in some cases has close and effective interaction with NGOs. Environment is one of the fields that are in dire need of a relationship between government and environmental NGOs. The extent and mutual dependency between environmental elements has made governments to assist civil institution's achievements as possible in order to protect environment.

The effective interaction between government and these organizations in execution and judicial control over environmental norms is important. Active organizations in environment section are regarded as civil society's awake eyes that are aware of the environment situation more that anyone and therefore, are able to react quickly in this regard with full awareness of the current situation.

The most important environmental problems in Iran in the current situation are: "overusing natural resources like north forests, polluting vital lifelines of rivers, destroying natural habitats, Oromia lake becoming dry and .... In order to overcome these difficulties, the government has to seek aids from NGOs and according to the measures taken by NGOs in the international level, it is necessary for internal NGOs to get prepared for playing such roles.

Given that in the international order NGO's role in the environmental field has increased significantly from the perspective of number and performance (this allegation is certified by the presence of almost 200 NGO as supervisors 
during Kyoto protocol negotiations and also their wide performance can be seen in the provisions of permanent committee of Bern convention. This committee has allowed the NGOs the verbal statements and written proposals inasmuch as even these proposals may be subject to polling in case of representatives' demand.) These extensive measures and the role of NGOs being highlighted, should be seek in their characteristics and their increasing power in addition to complexity and extent of environmental issues, as environment is one of the sciences that reaching the best conclusion depends on the relationship with other sciences and on the other hand is in need of comprehensive cooperation of all people in the national level and all international institutions. Besides, reaching environmental aims is accompanied by sacrificing interests of an amount of people therefore mostly there is less interest for execution. We can utilize increasing abilities of NGOs which often consider common interests to reach the highest level of cooperation. Despite constitutional law's emphasis on importance of environment and public obligation in keeping it in article 50, there are some deficiencies in control and protect order, one of these explicit deficiencies is about providing NGOs with roles. Despite NGO's key role in the process of formation and monitoring over environmental provisions' implementation all over the world, in Iran's law these organizations couldn't find their own position and play their main role and despite the role-taking capacity of these organizations, effective measures in order for direct partnership has not been considered. Therefore, these organization's activities often gets more practical than directly and officially be considered as the environment's trustee.

\section{Conclusion}

NGO's presence in some cases like humanitarian law, environmental law and development in international sphere is highlighted and in order to fulfill the determined tasks in their statutes or other international instruments takes measures to protect environment, cooperation and partnership in codifying provisions and legal standards in order to protect it and also have an effective presence in the process of monitoring over the implementation of these provisions. While in the national level, in most countries including Iran, NGOs ' role is not paid attention to and in spite of qualitative and quantitative variety of environmental NGOs in Iran and appropriate legal grounds for extending their activities, they do not receive the opportunity to express themselves officially.

The subject gets harder by this fact that during many years of establishment of environmental protection organization and trusteeship of Iran`s environment protection and specifically monitoring over implementation of environmental provisions we encounter the increasing process of environmental difficulties, destructions, pollutions and environmental crimes in a wide range. The wide range of these issues from the Oromia lake becoming dry to unlawful hunting and fishing the kinds in danger of extinction like Asian cheetah, reveals inefficiency of environmental protection organization and Iran's government specifically in protecting country`s environment. While the international community is aware of the necessity of the active presence of NGOs in order to codify and implement and supervise over implementation of environmental provisions, why it is not paid attention to in Iran, while these organizations are having such powers in other countries that stand against the government and as their government's strict rival in international assemblies reveal their secrets in violation the lawful provisions using the provided reports.

It seems that according to the roles of NGOs in international community and Iran's environmental difficulties within pollutions or unlawful hunting and fishing or irregular exploitation of forests and ranches, Iran`s environment development depends on establishing an appropriate and effective legal regime in order to protect the environment. On one hand, this needs advanced provisions that is consistent with current situation of Iran's environment and on the other hand requires establishing or strengthening modern and advanced supervisory institutes with the aim of monitoring dangerous environmental activities and gathering related information and reporting the environmental crimes to judicial authorities. Traditional institutions lack this characteristic therefore we can submit this role to NGOs that operate as the executive organ of the environmental protection organization. In this way we can grant the NGOs a role besides lawful trustees of the environment and include them in the lawful structure of environmental protection officially.

\section{References}

Betsill, M. M. and Correll, E. - NGO Diplomacy: The Influence of Nongovernmental Organizations in International Environmental Negotiations - MIT Press - Cambridge - 2008

Beigzade, Ebrahim- " - Non-governmental organizations and international legal Law Research Journal of Shahid Beheshti UniversityVul 31\&32- 2000.

Beyerlin, Ulrich - The role of NGOs in International Environmental litigations - Stockholm Universities Bibliotek - 2009

Bombay, Peter- European Environment Review, The role of Environmental NGOs in International Conferences \& Agreements - 2001 
Burleson, Elizabeth - Non-State Actor Access and Influence in International Legal and Policy Negotiations - Pace Law Faculty Publications - 2010

European Environment Agency, Global governance - the rise of non-state actors: A background report for the SOER 2010 assessment of global megatrends

Francoise Burhenne-Guilmin - "A Law for the Environment" - Essays in Honour of Wolfgang E. Burhenne (Gland: IUCN, 1994) - pp. 1720

Gholshan Chehre, Mohammadreza- - Non-governmental organizations and their role in the development and promotion of the rights of Thehran University.

Gupta, Joyeeta - "The Role of Non-State Actors in International nvironmental Affairs" - Max-Planck-Institut für ausländisches öffentliches Recht und Völkerrecht - 2003

Haji Valimirza, Sara- A study on the process of the development of international environmental law in the context of international SR Branch of Islamic Azad University of Tehran-2006.

ICJ Cases/available on http:icj.org/files

Kiss, Alexandre - Droit international de l'environnement - 2004 : E Book - p. 132

Kubasek,K and Nancy Gary S. Silverman - Environmental Law -Pearson - 2011: E Book

P. Birnie \& A. Boyle - International Law and the Environment - 2nd ed - 2002

UNEP, International Institution and Civil society, 2009

Young, O. R. - Institutions and Environmental Change - Cambidge, MA - MIT Press - 2009

First development program cod, 1989

Second development program cod, 1994

Third development program cod,1999

Fourth development program,2004.

Fifth development program, 2011.

Environment protecting organization`s official website, 2014 